Revue d'histoire de l'Amérique française

ZAS REVUE D.HISTOIRE DE L'AMÉRIQUE FRANÇAISE

\title{
The Policy of "Francisation" as Applied to the Indians During the Ancien Regime
}

\section{George F.G. Stanley}

Volume 3, numéro 3, décembre 1949

URI : https://id.erudit.org/iderudit/801575ar

DOI : https://doi.org/10.7202/801575ar

Aller au sommaire du numéro

Éditeur(s)

Institut d'histoire de l'Amérique française

ISSN

0035-2357 (imprimé)

1492-1383 (numérique)

Découvrir la revue

Citer cet article

Stanley, G. F. (1949). The Policy of "Francisation" as Applied to the Indians During the Ancien Regime. Revue d'histoire de l'Amérique française, 3(3), 333-348. https://doi.org/10.7202/801575ar d'utilisation que vous pouvez consulter en ligne.

https://apropos.erudit.org/fr/usagers/politique-dutilisation/ 


\section{THE POLICY OF "FRANCISATION" AS APPLIED TO THE INDIANS DURING THE ANCIEN REGIME}

When two systems of culture come into conflict with one another, the weaker, or more primitive, invariably succumbs to the stronger. Moral disintegration and physical decline are the usual results: although geography and climate may, upon occasions, intervene to permit a gradual adjustment on the part of the primitive culture to the altered circumstances arising out of contact with the more complex culture. Usually, however, there is no alleviating factor, and the cultural system of the primitive race, with little to sustain it, tends to fall to pieces. All over the world primitive peoples have paid a heavy price for the "benefits" of civilization.

Such, in part, is the story of the red man, the native aboriginal, in Canada. The tribal basis of Indian life precluded united opposition to the Europeans at a time when the Indians enjoyed numerical superiority. Despite occasional attemps by Indian leaders like Pontiac, Brant and Tecumseh to unite the native tribes, the Indians warred among themselves and became not only the victims of European economic exploitation but the pawns of imperialistic politics. Meanwhile the infiltration of explorers, traders, soldiers, missionaries and settlers never ceased until ultimately the Indians became an insignificant minority group almost lost in a preponderant white population.

The early arrivals among the white men in Canada were not wholly unappreciative of the problems of cultural contact. Missionary and government official both saw the necessity of making some effort to help the Indians bridge the gap between the stone age in which the first explorers found them and the civilization of 17th century Europe. However much they might differ in the solution proposed, both church and state recognized the existence of an "Indian problem". Policies were put into effect which bear striking resemblance to those with which we are familiar at the present time; these policies, moreover, 
in effect, still govern the relations of red and white man in Canada. Historical perspective is thus an essential requirement for an understanding of contemporary problems of culture conflict in this country.

Until the founding of the first French settlements at Port Royal and Quebec during the early years of the 17th century, the contact between the Indians and the Europeans had been only casual and intermittent. It had been confined to the occasional meeting of explorer, fisherman and trader with the Indians frequenting the Atlantic coast or the banks of the St. Lawrence river. However, with the establishment of colonies upon a permanent basis, occasional contact gave way to continuous pressure. Wars between England and France might alter or retard the tempo of European penetration but at no time did it disappear. To the Indian, European pressure must have seemed a continual and single process. From the day that Poutrincourt and Champlain met the Micmac sagamore, Membertou, the Indian and his culture were exposed to the steady infiliration of European blood and European civilization. And with this infiltration began what is called "the Indian problem" in Canada.

Although the French never recognized any aboriginal proprietary rights in the lands which they proceeded to occupy from 1604 onwards ${ }^{1}$, they never entertained any idea of deliberately dispossessing the Indians. The aboriginal was never regarded as an alien in New France; he was looked upon as a subject. He was not to be liquidated; he was to be civilized. From the outset it was intended that he should become an integral part of the colony as it developed. He was to become a Frenchman in manners, language and religion if not in blood; in short, he was to become "francise".

1. This was in accord with the well understood ideas of international law of the period. Savage peoples were not considered as members of that entity known as "the family of nations" and were not, therefore, regarded as possessing any proprietary rights in the lands which they occupied. This concept was expressed in 1758 in the treatise written by the Swiss jurist, Emer de Vattel. Vattel laid down the principle that occupancy by wandering tribes "cannot be held as real and lawful taking possession; and when the Nations of Europe, which are too confined at home, come upon lands which the savages have no special need of and are making no present and continuous use of, they may lawfully take possession of them and establish colonies in them". (C.G. Fenwick, International Law (New York and London, 1924), 223). Although the British adopted the practice of purchasing lands from the Indians this did not mean that they recognized the Indian tribes as sovereign nations; it was simply a matter of expediency, a convenient means of avoiding an Indian war not a matter of securing a valid title in law. 
The Jesuits were the first to attempt to carry out this policy of "francisation" or amalgamation of the French and Indian races. A few conversions had been made by the Recollets and the Jesuits during the first years of New France but with the arrival of Father Paul Le Jeune in Quebec as Superior of the Jesuit Missions in New France, on 5 July 1632, the policy of gallicization began in earnest. Le Jeune's aim was, in a few words, to teach the Indians French ways, the French language and the Catholic catechism. He approved a proposal to send specially selected Indians to France for instruction; but his heart was set upon the establishment of schools in Canada to which Indian children might be sent and where they might be shielded from the barbarous influences of their home surroundings while acquiring the virtues of civilization. Father Le Jeune pinned great hopes upon the education of the young as the best means of bringing European civilization to the Indians and providing them with the means of adapting themselves to the pattern of life brought by the Europeans to Canada from France. The products of these schools, he hoped, would be indistinguishable from the French colonists, except in colour and racial features. Education was to be the means whereby the Indian and French peoples might form a Canadian amalgam.

In pursuance of this aim a school was opened in Quebec in 1635. It was attended both by white and Indian children. In 1636 Father Le Jeune wrote in his Relation:

Nous avons commencé à enseigner dès l'année passée: le Pere Lallemant, \& puis après le Pere de Quen ont instruit nos petits François, \& moy quelques petits Sauvages. ${ }^{2}$

Le Jeune's real ambition was, however, to establish a seminary or boarding school. He therefore urged upon his superiors in France that the best way to convert and civilize the Indians

seroit de dresser icy un seminaire de petits garçons, \& avec le temps un de filles, soubs la conduitte de quelque brave maistresse, que le zele de la gloire de Dieu \& l'affection au salut de ces peuples, fera passer icy, avec quelques Compagnes animées de pareil courage. ${ }^{3}$

2. Jesuit Relations and Allied Documents, Ed. R.G. Thwaites, (73 vol., Cleveland, 1896-1901), VIII: 226.

3. Ibid., VI: 150 . 
He made it clear that the Indian children must be removed from the influence of their parents:

...ces Barbares ne peuvent supporter qu'on chastie leurs enfants, non pas mesme de paroles, ne pouvans rien refuser à un enfant qui pleure, si bien qu'à la moindre fantaisie ils nous les enleveroient devant qu'ils fussent instruicts; mais si on tient icy les petits Hurons, ou les enfants des peuples plus esloignez, il en arrivera plusieurs biens; car nous ne seront pas importunés ny destournés des peres en l'instruction des enfants; cela obligera ces peuples à bien traitter, ou au moins à ne faire aucun tort au François qui seront en leur pays. ${ }^{4}$

Towards the end of July 1635 the seminary opened its doors to three Indian pupils. Father Brébeuf had promised twelve, but at the last moment several Indian parents refused to part with their children, while some of the little Indian boys who had already set out for Quebec became homesick and returned to the parental lodges. Even with but three pupils the good Fathers had their troubles. The boys arrived practically naked and had to be clothed; presents had to be made to the parents to ensure their continued co-operation; and there were funds neither for the upkeep of the children nor the payment of the instructors. One pupil proved intractable and could not get along with his fellows; others suffered from illness. The fact is that the Indians did not thrive under European conditions and the Fathers were obliged to make belated modifications both in the diet and dress of their savage charges.

The regimen of the school was not severe. Prayer, attendance at mass, a little school work and a great deal of recreation, hunting and fishing and long walks constituted the daily programme. Anything more demanding would have aroused resentment and rebellion on the part of the young Indians whom Father Le Jeune likened to wild asses colts "ne rendant aucune subjection à qui que ce soit, sinon quand il leur plaist". ${ }^{5}$ It was not part of the Indian cultural pattern to give implicit obedience to their chiefs. The tribesmen might be persuaded but not driven, influenced but not ordered. Again citing Father Le Jeune:
4. Ibid., 152.
5. Ibid., 242. 
Ils m'ont reproché cent fois que nous craignons nos Capitaines, mais pour eux qu'ils se mocquoient \& se gauffoient des leur: toute l'authorité de leur chef est au bout de ses levres, il est aussi puissant qu'il est eloquent; \& quand il s'est tué de parler \& de haranguer, il ne sera pas obey s'il ne plaist au Sauvages. 6

The seminary carried on its work for several years but it was not, however reluctant Father Le Jeune may have been to admit the fact, a success. The Hurons, from whom much had been hoped because of their sedentary habits, came in small numbers to the seminary; and the Algonquins and Montagnais children who were invited to attend when the Hurons failed to fill the vacancies, proved highly susceptible to disease and equally inclined to return home whenever the whim to do so should take possession of them. Finally, after five years of struggle, the project was abandoned. In the Relation of 1642 Father Vimont stated that the Jesuits had been forced to give up the seminary experiment "pour de justes raisons \& nômement par ce que l'on ne voyoit pas de fruict notable parmy les Sauvages". ${ }^{7}$ The first attempt to transform the Indians by educating a few children in the French manner had failed.

Although Father Vimont's explanation is brief and to the point, there were other factors which explain the failure of Le Jeune's seminary. Certainly neither devotion nor effort were lacking. The first great obstacle which the Fathers could not overcome was the unwillingness of the Indian parents to part with their children; the second was the unwillingness of the Indian children to remain within the four walls of a school far from the woods and streams they loved and far from their own people. They longed for liberty, for the hunt and the chase; they wanted neither the food, the clothes, the studies nor the regulations of the boarding school. At best they would remain but one or two years and then return home with a smattering of useless knowledge to revert all too soon to the ways which were familiar to them. A little knowledge often proved worse than none at all. The Indians were, after all, little better than savages, during the period under review. The labour and self sacrifice of the missionaries might influence the outward demeanour of a few Indians in even fewer respects,

6. Ibid., 242.

7. Ibid., XXIV: 102. 
but the efforts to christianize, educate and gallicize left their individual tempers and their tribal dispositions essentially unregenerate.

The attempt to "franciser" little Indian girls was attended with scarcely more success. In 1636 Le Jeune wrote that several Indian families had given over their daughters to be housed with French families in Quebec. In his Relation for that year he wrote:

Ces pauvres mécreans... nous ont donnez quelques unes de leurs filles, ce qui me semble un coup de Dieu. Ces petites filles étans nourries à la facon des Chrestiens, puis mariées à quelques Francois ou quelques Sauvages baptisez, retireront tant d'enfans de leur Nation que nous voudrons.8

Some of these little girls he proposed to send to France:

Afin de les dépaïser, \& de leur donner le moyen d'apprendre la langue, \& l'honnesteté Françoise, pour secourir par après leurs compatriotes; nous avons déliberé d'en envoyer deux ou trois en France, pour les faire loger \& instruire en la maison des Hospitalieres qu'on desire faire passer en la Nouvelle France. ${ }^{9}$

In $1639 \mathrm{Mme}$ de la Peltrie and the Ursulines arrived in Canada. To them was entrusted the task of educating little Indian girls. Unlike the boys, the girls proved docile, tractable and obedient - the early missionary letters are full of accounts of their piety - but like the boys they proved incapable of transformation into Europeans within a few years. There is no doubt that the Ursulines did much to soften the manners of a barbarous race, but the step from the skin or bark lodge to the convent was a long one. Marie de l'Incarnation fully appreciated this fact. In one of her letters to her son she wrote that it was difficult if not impossible to civilize the Indians and to raise them in the French manner. The letter continued:

Nous en avons l'experience plus que tout autre et nous avons remarqué de cent de celles qui ont passé par nos mains, à peine en avons-nous civilisé une. Nous y trouvons de la docilité, et de l'esprit, mais lorsqu'on y pense le moins, elles montent par dessus notre clôture et s'en vont courir dans les bois avec leurs parents, où elles trouvent plus de plaisir que dans tous les agréments de nos maisons françaises. L'humeur sauvage est faite de la sorte; elles ne peuvent être contraintes; si elles le sont, elles deviennent mélancoliques, et la mélancolie les fait malades. ${ }^{10}$

8. Ibid., IX: 102.

9. Ibid., 102.

10. Sr Marie-Emmanuel, Marie de l'Incarnation d'après ses Lettres (Ottawa et Québec, 1946), 122. 
Like the Jesuits, the Ursulines soon arrived at the conclusion that the amalgamation of the French and Indians in Canada was not to be achieved solely in the convent cell or in the class room.

Theory, however, rode roughshod over experience. At a time when both the Jesuits and the Ursulines had virtually abandoned the policy of "francisation" realizing its impracticality under the conditions then prevailing, the civil authorities, under the impetus of King Louis XIV and his minister Jean-Baptiste Colbert, undertook to revive it. Lacking any first hand knowledge of the difficulties encountered by the religious orders, theorists and pedagogues in France advanced the arguments that the Indians could be reclaimed by the simple process of education and intermingling of the two races an argument which has, incidentally, displayed remarkable powers of longevity. In essence the idea was simply that the primitive Indians, witnessing the material advantages of French civilization, would seek to emula te the Europeans and copy their ways. But this view had already proven fallacious. It was, indeed, based upon a false premise; for the Indian did not look upon himself as inferior to the white man. Rather, he looked down upon the European as ignorant of the ways of the woods and envied only his tools and his weapons and not his culture, clothes and education. In fact the emulation came from the French and not from the Indians. One of the great social problems of New France was the steady drain upon its human resources of the young men, who, copying the Indian way of life, sought to free themselves from the restraints of civilization, by taking to the woods. Both king and minister, however, were persuaded that if the policy of gallicization had been a failure, that failure was due, not to any weakness in the policy per se, but simply to the half hearted and inadequate support accorded it by the clergy. All that was required to achieve success was greater effort. In a despatch to the Intendant of New France, Jean Talon, Colbert wrote:

Je vous avoüe que j'ay juge comme vous que l'on s'est fort peu soucié jusques icy de la police et de la vie civile en Nouvelle France envers les Algonkins et les Hurons qui sont il y a longtemps soumis à la domination du Roy en faisant peu d'efforts pour les destacher de leurs coustumes sauvages et les obliger à prendre les nostres, et sur tout à s'instruire dans notre langue, au lieu que pour avoir quelque commerce avec eux nos françois ont été necessitez d'apprendre la leur. Vous avez commen- 
cé de remedier à cette longue negligence. Et vous devez tascher d'attirer ces peuples sur tout ceux qui ont embrassé le Christianisme dans le voisinage de nos habitations et s'il se peut les y mesler, afin que pour la succession du temps n'ayant qu'une mesme loy et un mesme ministre ils ne fassent plus ainsy qu'un mesme peuple et un mesme sang. ${ }^{11}$

The whole object of the civil authorities was summed up in the words "in order that in the course of time... they might thus constitute one people and one race".

The voice of Colbert's policy was that of Jean Talon, but the hands were to be those of the clergy. There was no civil Indian Department in New France and it was never intended that there should be. The regulation of the fur trade and the employment of the Indians in war were matters clearly within the competence of the intendant and governor: education was the handmaiden of evangelization, and the clergy, who already had extensive contacts with the Indian tribes through their various missions, were the natural people to bring the Indians to an understanding of and participation in civilization. On 2 March 1668 Louis XIV wrote to Bishop Laval urging him to encourage the missionaries to continue their efforts to persuade the Indians to give up their barbaric way of life and adopt that of the French, to leave their homes in the wilderness and move into the French settlements "pour ne plus faire qu'un mesme peuple, parceque sy on venoit à bout de ce point là il seroit plus aysé ce semble de leur faire embrasser notre religion". ${ }^{12}$ If the older Indians should prove reluctant to take so drastic a step, then attention should be devoted to winning over the children and educating them in the French manner: the missionaries should be obliged, wrote the king, to make "toutes sortes d'efforts pour les obliger à donner leurs enfans pour les eslever à la maniere de vivre des françois et les instruire en la connaissance de notre religion". ${ }^{13}$ It was all very familiar. Father Le Jeune had used practically the same words a generation earlier.

In response to the royal instruction Laval set in motion a policy which was practically identical with that which Father Le Jeune had

11. Talon to Colbert, 13 Nov. 1666, Public Archives of Canada, C 11A, 2: 332. 12. Louis XIV to Laval, 2 Mar. 1668, PAC, Affaires Etrangères, Mémoires et Documents, Amérique, 5 pt. 1: 303.

13. Ibid. 
inaugurated and discarded, even to the establishment of a seminary for Indian boys at Quebec. In a letter to Paris, dated 8 November 1668, the bishop wrote:

Comme le Roy m'a témoigné qu'il souhaittoit que l'on tâchast d'élever à la maniere de vie des François, les petits enfans Sauvages, pour les policer peu à peu; j'ay formé expres un Seminaire, où j'en ay pris un nombre à ce dessein; \& pour y mieux réussir, j'ay esté obligé d'y joindre des petits François, desquels les Sauvages apprendront plus aisément, \& les mœurs \& la langue, en vivant avec eux. ${ }^{14}$

Such was the beginning of the Petit Séminaire, an institution destined ultimately to grow into the great university bearing Laval's own name.

The Jesuits were not the only religious order to be enlisted in support of the revived policy of "francisation". The Sulpicians too endeavoured to carry out the king's wishes. In 1668 the Gentlemen of St. Sulpice in Montreal opened a school of which Talon, suspicious of the good faith of the Jesuits, wrote in high praise to Colbert in 1670.

Vigour did not, however, bestow virtue upon a discredited policy. It is obvious from the repeated instructions from Paris that the renewed efforts at "francisation" had been attended with less than the expected success: what is still more obvious was the failure of the Indians, despite the efforts of church and state, to embrace the white man's civilization in its better aspects in any considerable numbers. Nevertheless, rather than capitulate to the logic of the facts the rhetoricians of Paris continued to demand still greater efforts from the missionaries. Neither king, minister nor intendant seem to have devoted serious study to the problem of racial contact; not, at least, in a way which revealed to them the difficulties, complexities and delays necessarily attending any scheme of amalgamating the red and white peoples in Canada. They were impatient of results and therefore prone to lay the blame not upon the problem but upon those who had not yet solved it.

In 1672 Count Frontenac arrived in Quebec to take over the reins of government. Completely ignorant of Indians character and totally unaware of the real nature of the Indian problem, he was amazed that the Indians, even those in the missions near Quebec, did not act and speak like Frenchmen. That the aborigines were not further

14. Jesuit Relations, LII: 46. 
along the road to racial amalgamation Frontenac at once attributed to the ill will of the Jesuits. His correspondence with Paris is marked by repeated assertions that the religious order were not only failing to carry out the royal will with respect to the Indians but that they were actually placing obstacles in the way of its achievement. Colbert shared Frontenac's prejudices. In one of his letters to the Governor, dated 13 June 1673, he wrote:

Sa Majeste m'ordonne particulièrement de vous dire que comme toute vostre application doibt tendre à augmenter la colonie pendant le temps que vous demeurerez en ce pais là, non seulement il faut travailler à y attirer de nouveaux Français du Royaume et à prendre soin de la conservation de ceux. qui y sont par les mariages... mais mesme en attirant les sauvages dans la société et dans la forme de vivre des Français; et comme jusques à présent il paraist que les Jésuites ont eu des maximes contraires que les prestres de Seminaire habituez à Montréal ne s'y sont pas appliquez, et que les Récolletz n'ont pas encore eu assez de temps pour cela, Sa Majesté veut que vous vous appliquiez fortement à changer cette disposition et à les porter tous également ou par émulation les uns à l'egard des autres à agir sans cet esprit de libertinage qu'ont tous les sauvages en celuy d'humanité et de société que les hommes doibvent avoir naturellement et pour cela Sa Majesté estimerait bien à propos que chacune de ces communautez prist un nombre d'enfans sauvages pour les eslever dans la connaissance de nostre religion pour en faire avec le temps de bons habitants. ${ }^{15}$

During the summer of 1673 Frontenac met a delegation of Iroquois at Cataraqui. In the course of his address to the assembled Indians he suggested that they might let him have some of their children for the purpose of educating them in New France. This appeal had a familiar ring about it; it was the same appeal which Fathers Le Jeune and Brebeuf had made to the Hurons without notable success. The Iroquois delegates temporized by asserting that they would first be obliged to consult their several tribes; but Frontenac was filled with confidence and enthusiasm. On 13 November he penned a letter to Colbert drawing the minister's attention to his dutiful compliance with the king's wishes and contrasting it with the dilatory

15. Colbert to Frontenac, 13 Jun. 1673, Rapport de l'Archiviste de la Province de Québec, (1926-7): 25. 
actions of the clergy. "Je leur ai prêché cet Evangile", he wrote, "dès le premier jour que je suis arrivé et leur ai dit que j'étais scandalisé de voir à deux lieues de Québec des Sauvages aussi peu français que s'ils n'en avaient jamais vu". ${ }^{16} \mathrm{He}$ was unwilling to admit that the fact that the Jesuits did not share his enthusiasm for "francisation" might possibly stem from their greater knowledge of Indian character and their greater experience of the Indian problem. To Frontenac the Jesuit attitude was inspired simply by a desire to keep the Indians under continued tutelage. To Colbert he wrote:

tenant les Sauvages comme ils font, ils en sont les seuls maitres et les font servir à ce qu'ils veulent... ils appréhenderaient à mon avis s'ils vivaient comme nous, qu'ils ne voulussent sortir de leur tutelle et partager la plupart des terres dont les PP. Jésuites jouissent ici....

To everyone's surprise the Iroquois delegates returned with the acquiescence of the Confederacy in Frontenac's proposal and brought with them several children, both boys and girls, to be educated at Quebec. Here was the justification of Frontenac's policy; here too was the opportunity to give a back hand slap at the Jesuits. One can sense the Governor's glee as he wrote:

Les Pères Jésuites qui les connoissent mieux que personne y ont esté les premiers trompez, et n'ont jamais pû croire que lors qu'ils l'ont veu qu'ils se resolussent à me donner de leurs enfans. ${ }^{18}$

Full of confidence Frontenac proceeded to outline in a letter to Colbert what he proposed to do with the Iroquois children:

L'aumosne que vous avez eu la bonté de procurer aux meres ursulines est venue fort à propos pour l'entretienement de ces enfants, ayant mis les quatres filles chez elles, de sorte qu'avec les six huronnes quelles avoient des-ja, elles ont dix petites sauvagesses presentement, quelles instruisent avec un succes qui donne de l'édification à tout le monde... Pour les quatres petits garçons Iroquois, comme il y en a deux qui sont fort jeunes je les ay mis en pension chez une femme qui en a grand

16. Frontenac to Colbert, 13 Nov. 1673, Ibid., 34 .

17. Ibid.

18. Frontenac to Colbert, 14 Nov. 1674, Ibid., 65. The copy of this despatch in the Public Archives of Canada (C 11A, 4: 163) bears the date 12 November 1674. 
soin, et où ils seront entretenus sur le reste des charitez que jay receues, et pour les deux autres qui ont neuf ou dix ans, je les fais eslever chez moy à mes despens, et les envoieray instruire tous les jours ches les pères jésuites. ${ }^{19}$

Four small boys and four little girls did not, however, constitute an Indian nation, and Frontenac, despite his lengthy despatches was able to show but meagre results for all his words and his efforts. A review of the letters exchanged between Quebec and Paris in the years which followed leads almost inescapably to the conclusion that the French Government was either losing its faith in the possibility of "francisation" or in Frontenac's ability to carry this policy to a successful conclusion. Nothing appears in the royal letters to Frontenac between April 1676 and April 1679 on the subject of domestic Indian policy. Nor was Frontenac himself inclined to waste much time or energy upon attempts to civilize the Indians; he was too deeply involved in the fur trade and in controversies with the Intendant and the Bishop over the use of brandy as an article of trade to bother much about gallicizing the native peoples. Furs rather than souls were his real concern. Perhaps, too, his own belief in "francisation" had begun to weaken. Certainly his letter to the king, dated 6 November 1679, despite the usual complaints about the Jesuits and the Ursulines, lacks the hearty confidence which characterized his earlier communications. ${ }^{20}$ And the absence of further comments upon the domestic Indian problem in his subsequent despatches suggests that he, no less than his superiors, was becoming convinced of the futility of trying to turn large numbers of Indians into Frenchmen by the simple process of educating a few children in seminaries, convents, or even in the governor's household.

The arrival of de Meulles as Intendant witnessed a partial revival of the policy of promoting civilization among the Indians by introducing European ways and crafts. During de Meulle's administration an attempt was made to teach the Indian children various trades and European hand skills. The Intendant proposed, in particular, that Indian girls should be taught peasant crafts, such as spinning and weaving, as well as the care of domestic animals. These skills they

19. Ibid. 5: $25-6$. 
would carry with them when they returned to their homes. He also suggested that the Christianized Indian girls might be given a dowry of a cow, a pig and some grain upon marriage. But this was not, strictly speaking, "francisation"; and by the time that Governor Denonville penned his despatch of 13 November 1685 "francisation" was ready for interment in the archives of history.

Denonville's despatch is one of considerable interest. It marks the first expression of disapproval of the policy of "francisation" to be found in any document emanating from a civil as distinct from an ecclesiastical source. Denonville's remarks leave no doubt as to his attitude:

L'on a creu bien longtemps que l'aproche des sauvages de nos habitations estoit un bien tres considérable pour acoutumer ces peuples à vivre comme nous et à s'instruire de notre religion, je m'aperçoy, Monseigneur, que tout le contraire en est arrive car au lieu de les acoutumer a nos loys, je vous asseure qu'ils nous communiquent fort tout ce qu'ils ont de plus mechant, et ne prennent aux mesmes que ce qu'il y a de mauvais et de vitieux en Nous.... ${ }^{21}$

The mixing of the races had not, in the space of fifty years, since Le Jeune began his little school with French and Indian pupils in 1635, led to the betterment of the Indians. What was more alarming was that it had led to a weakening of the moral fibre of the whites. Each race had, in contact with the other, tended to absorb the worst rather than the best features of the other's culture. Drunkenness became a feature of every Indian encampment while immorality marked the path of the coureur de bois. More than one Governor in New France deplored the loss of so many young Canadians from the settled communities along the St. Lawrence. The abandonment of "francisation", if notadvisable in the interests of the Indian was becoming increasingly necessary in the interests of the white man: it had become a question of preventing the "Indianizing" of the French rather than of gallicizing the Indians. The freedom of Indian life held far greater attraction for the virile spirits of the young French Canadians than the constraints of civilization had ever held for the young Indians. Governor Denonville wrote:

21. Denonville to the Minister, 13 Nov. 1685. PAC, C 11A 7: 46-7. 
...on a traitte de gentillesse et de plaisanterie une facon de se mettre en habits de sauvages tous nuds, non seulement aux jours de carnaval mais à tous les jours de regal et de debauche toutes ces manières ne tendent qu'a entretenir les jeunes lgens dans l'esprit de vivre en sauvages, et de se communiquer avec eux, et d'estre eternelement Libertins comme eux. Je ne sçaurois Monseigneur assez vous exprimer l'atrait que les jeunes gens ont pour cette vie de sauvage qui est de ne rien faire, de ne se contraindre pour rien, de suivre touts ses mouvemens et de se mettre hors de la correction. ${ }^{22}$

During the second administration of Frontenac (1689-1698) the question of "francisation" arose once more, but only as a stick which the Governor might beat the Jesuits. The policy had failed to achieve any concrete results and it had never been, after all, very close to Frontenac's heart. The "Great Onnontio" acquired sufficient knowledge of Indian psychology to be able to join in Indian ceremonies, to don Indian headdress and wave an Indian tomahawk, to impress the Iroquois with a show of force and to orate in the Indian fashion; but he never had any real appreciation of the sociological aspects of the Indian problem. He had no contribution to make towards solving the problem of conflict of cultures in Canada.

By the beginning of the 18th century the French civil authorities had pretty well washed their hands of the Indian problem. They were prepared to leave it to those who had first grappled with it, the missionaries. Henceforth, one may look in vain in the Governor's or the Intendant's letters for constructive suggestions as to how the civil authorities might deal with the problem. There are, of course, many pages devoted to the regulation of the fur trade and to the employment of the Indians in the defence of Canada; but only here and there do we find incidental references to the problem of reconciling the Indians to the civilization which was already threatening to engulf them and their culture. This was now a matter for the church; and the church, having tried and discarded the policy of mixing the races in the pious hope that the Indians would, by emulation, raise themselves to the level of the whites, had adopted the policy of gathering their charges into Indian villages, teaching them the rudiments of agriculture and the catechism, screening them from contact with the whites and allowing them to retain their own tongues and sense of

22. Ibid., 45-6. 
their identity. It was a policy which they hoped might make Christians but not necessarily Frenchmen out of the Indians. Fundamentally it was a policy of segregation rather than amalgamation; and Sillery, Jeune Lorette, St. François de Sales, Oka and Sault St. Louis were the first of the Indian "reservations" in Canada.

The question poses itself: why did the policy of "francisation" fail? Partly because neither church nor state was able or willing to put up the funds required - even to clothe the Indians in the French manner was beyond their means: partly because the numbers educated were so few and the period of schooling so short that, as Father Charlevoix remarked in his Histoire et Description Générale de la Nouvelle France, "le sang et la nature reprenoient bientôt le dessus, et il ne leur restoit de la bonne éducation, qu'on leur avoit donnée, que plus d'ouverture d'esprit et des connoissances, qui leur devenoient pernicieuses par l'abus, que la plupart en faisoient": ${ }^{23}$ partly because of the unwillingness on the part of the Indian parents to co-operate fully with the Europeans who believed that they were helping the Indians. More fundamental was the will of the Indian to survive as such. In order to ensure the success of any policy of racial assimilation two factors seem to be pre-requisites; namely, the people to be absorbed must be fewer in number than those absorbing them, and they must possess a weak sense of their own identity as a people. If either of these factors is absent, racial assimilation is difficult if not impossible to achieve. In the case of the Indian tribes with whom the French were dealing, neither of these factors was present. It was not because of any indifference on the part of the religious orders or lack of effort on the part of the civil authorities of New France that the Algonquins and the Hurons did not make "one race and one people "with the French, whatever we may read in the despatches of Frontenac and Talon. "Francisation" was a policy which, under the circumstances prevailing during the Ancien Regime, was not capable of realization as long as the Indians were strong in numbers and imbued with an equally strong will to survive as a race.

In 1709 the author of the Relation par Lettres de l'A mérique Septentrionalle wrote with prophetic insight of the Indian problem in Canada:

23. Le R. Père F.-X. de Charlevoix, S.J., Histoire et Description Generrale de la Nouvelle France (3 vols., Paris, 1744), I: 344. 
Il faudra un travail et un tems infiny pour affranchir ces peuples et pour pouvoir les réduire à prendre nos usages et nos coutumes, ce ne sera que par une application continuelle sur eux et peu à peu qu'on y pourra parvenir, et c'est, je vous assure, un ouvrage de plusieurs siecles. ${ }^{24}$

George F.G. Stanley,

Professor of History, Royal Military College of Canada, Kingston, Ont.

24. Relation par Lettres de l'Amérique Septentrionalle, (année 1709 et 1710) Ed. le R. Père C. de Rochemonteix, S.J. (Paris, 1904), 62. 